\title{
BACKGROUND FOR INTRODUCTION OF BAT SYSTEM IN INTENSIVE DAIRY FARMING IN RUSSIA
}

\author{
Alexander Briukhanov, Eduard Vasilev, Natalia Kozlova, Ekaterina Shalavina \\ Institute for Engineering and Environmental Problems in Agricultural Production, Russia \\ sznii@yandex.ru
}

\begin{abstract}
Currently Russia is realising the transition to the BAT system in different spheres of economy. Russian BAT reference books on intensive rearing of pigs and intensive rearing of poultry have been developed and come into force on June 1, 2018. The paper presents the study outcomes of dairy farming in Leningrad Region in terms of its environmental impact. The main features of current dairy farming are large-scale enterprises and concentration of livestock on separate sites. This results in accumulation of animal manure near the farms and increases the risk of nutrient leakage into the water sources and ammonia emissions into the atmosphere. The top-priority environmental challenge in animal farming in Leningrad Region is manure utilisation on big farms with substantial manure output. Manure processing technologies applied on dairy farms in Leningrad Region were estimated by the BAT criteria, namely, the least environmental effect, high economic efficiency of implementation and operation, and the use of resource and energy saving practices. Ecological estimation of cattle farms was based on indicators of nitrogen use efficiency. The list of required initial data to develop the BAT reference book on intensive rearing of cattle and to select the key technologies to be identified as BAT candidates was compiled. Introduction of BAT technologies for manure processing, storage and field application will allow reducing atmospheric ammonia emissions by, at least, $20 \%$ and consequently cutting down the nutrients loss.
\end{abstract}

Keywords: ecological safety, best available techniques, agricultural production, waste, manure, intensive livestock farming.

\section{Introduction}

Currently, in Russia, in accordance with the Federal law on environmental protection, the transition to the system of best available techniques (BAT) is in progress in many sectors of the economy. In this process, Russia uses the European experience: BAT definition and main criteria for its identification are very similar in the EU Industrial Emissions Directive and the Russian environmental legislation [1;2]. The BAT system both in Europe and in Russia is considered to be a tool to mitigate the pressures on the environment.

The first step in transition to BAT principles for each industry is the development of BAT reference books. Russian BAT reference books on intensive rearing of pigs and intensive rearing of poultry have been developed and come into force on June 1, 2018 [3; 4]. The European reference book BREF [5] was used as an analogue.

The subject of this article is the topical issue of BAT approach application to dairy farms as well. The results of the research associated with environmental problems in milk and beef production, intensively conducted around the world, are reflected in a number of international and national legislative documents. The Guidance Document for preventing and abating ammonia emissions from agricultural sources of the Convention on Long-range Transboundary Air Pollution contains a list of relevant measures in dairy farming. Following its international obligations, the Russian Federation annually makes an inventory of hazardous emissions into the atmosphere and greenhouse gas emissions from all pollution sources, cattle included, by the methods from the relevant guidance documents [6; 7]. In Estonia, BAT reference book on cattle rearing structured as European BREF has been developed [8]. A large amount of information on manure management systems for all animal categories, cattle included may be found in [9].

Currently in Russia, the main characteristics, indicators and requirements for cattle farms are specified in the existing regulatory and legal documents for the construction and operation of livestock enterprises - Federal laws and codes, Federal and regional regulatory acts, guidelines, sanitary and veterinary standards, State standards and others. The main current guidance documents, which should be considered when developing the Russian Bat reference book on intensive rearing of cattle, are Management Directives for Agro-Industrial Complex "Recommended Practice for Engineering Designing of Cattle Farms and Complexes" [10] and "Recommended Practice for Engineering Designing of Systems for Animal and Poultry Manure Removal and Pre-application Treatment" [11]. 
The need for transition to the BAT system in intensive cattle rearing in Russia is explained by the significant contribution of this sector to environmental pollution, and, accordingly, the requirements to take efficient measures to reduce its negative impact, Fig. 1.

Ammonia $\left(\mathrm{NH}_{3}\right)$ is the main atmospheric pollutant from the livestock facilities [5]. The volume of ammonia emissions can be an indicator of the production scale, since it is directly related to the size of the animal stock. Fig. 1 shows the contribution of various branches of Russian livestock production to $\mathrm{NH}_{3}$ emissions into the atmosphere: dairy cattle and non-dairy cattle account for $40 \%$ of the total ammonia emissions in the European part of Russia.

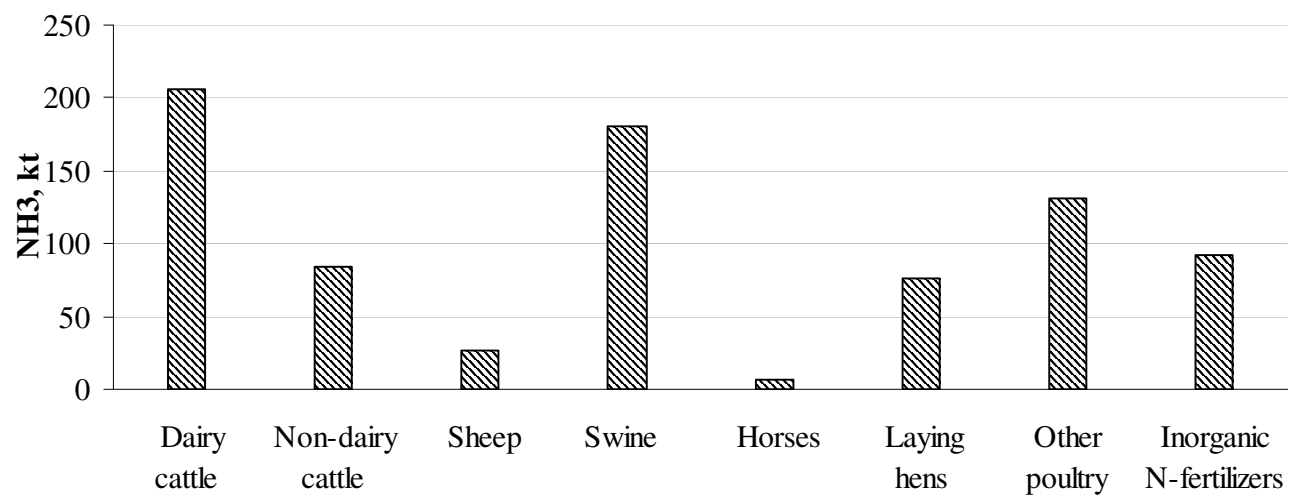

Fig. 1. Ammonia emissions from livestock farming in European part of Russia, EMEP report (2015)

The scientific and methodological basis to substantiate such a transition and to develop the information and technical reference books on BAT for cattle is the existing national and foreign experience in rational placement of farms and the use of effective technological solutions on them. This article examines the analysis results of milk production technologies by the BAT criteria with the aim to collect the baseline data for the development of the BAT reference book on cattle rearing.

\section{Materials and methods}

In the study the data from literature sources and open statistical data were used. The initial data for the Russian BAT reference book on cattle rearing was substantiated by analysing the situation in the industry and technologies in place on dairy farms in the North-West Russia, Leningrad Region in particular, by the BAT criteria (the least environmental effect, high economic efficiency of implementation and operation, and the use of resource and energy saving practices). A survey of 18 dairy farms in Leningrad Region was made. The information on existing technologies in animal husbandry, which is needed for a corresponding chapter of the BAT reference book, was collected by questionnaires related to: housing milking cows, tied; housing milking cows, loose; systems of manure storage, processing and application on each type of farms [17]. The following manure management technologies were considered: composting of solid manure on concrete pads + field-edge storing of produced fertilisers prior to application; biofermentation of manure in closed installations; storage and processing of liquid manure, lagoons; storage and processing of liquid manure, above ground and partially in ground storages. To describe the technologies as BAT candidates the detailed data from various public information sources were used. The method of environmental assessment of cattle enterprises using the indicators of nitrogen use efficiency was tested. The authors also made use of their work experience in Technical Working Groups on Russian BAT reference books on intensive pig rearing and intensive poultry rearing.

\section{Results and discussion}

The issues considered in the article result from the requirements for the structure and content of BAT information and technical reference books, which are fixed by the Russian regulatory documents developed in recent years [12].

The scope of the BAT system for cattle is not specified in the current legal documents. Similarly with the reference books on pigs and poultry, it is necessary to define the minimum number of animals 
on the farm, which should be attributed to the BAT system. When determining the scope of application, the degree of the impact of the facility on the environment and the degree of its prevalence are estimated.

Scope of application requires serious justification, since this scope affects the interests of agricultural producers and determines the environmental measure costs. Data on the size of cattle farms, see Fig. 2, and on the volumes of manure produced on one site show that enterprises with a one-time housing of 400 heads of cattle should fall within the scope of the BAT system.

Current development of livestock farming in Russia tends to large-scale enterprises and an increased number of animals on one site. This development pattern makes it possible to improve the competitiveness and efficiency of agricultural production through rational distribution of productive forces and introduction of high-performance, energy-saving technological solutions. However, as the experience of intensive development of agriculture has shown, the spot concentration of large animal stock creates significant problems in environmental compliance of enterprises. In the first place, these problems are associated with the utilisation of large volumes of animal and poultry manure [13].

Analysis revealed that dairy farming in Leningrad Region demonstrates the same development trend. Here above $15 \%$ of cattle farms have from 800 to 1000 heads, Fig. 2.

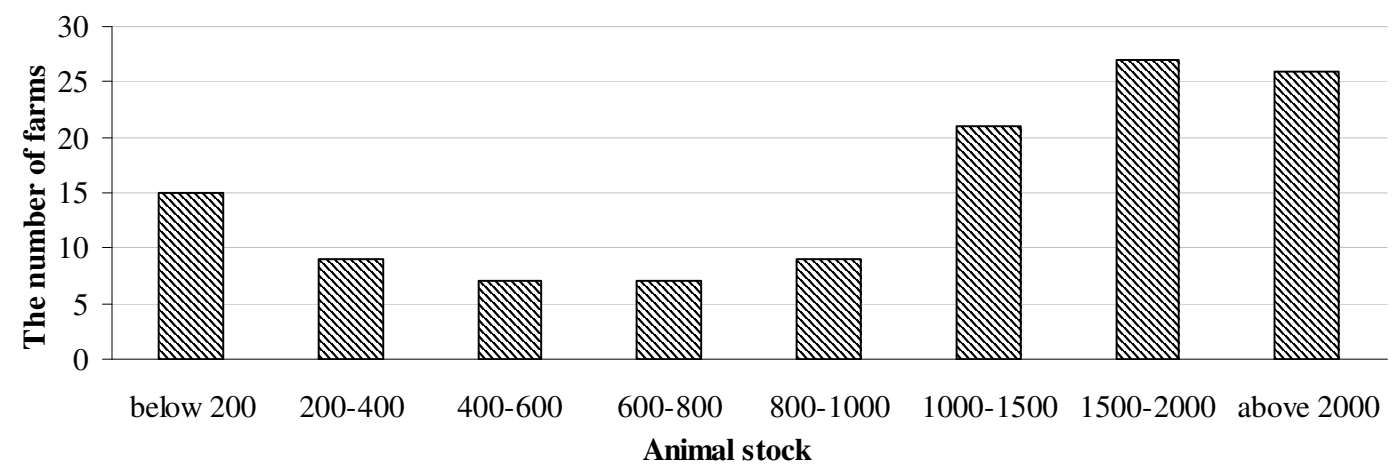

Fig. 2. Capacity of dairy farms in Leningrad Region, 2015

In most cases dairy farms rear the replacement stock of their own. The transition to the loose all-yearround stable housing of cows is in progress. The share of tied housing of farm animals is around $88 \%$ in the Russian Federation, and around $60 \%$ in Leningrad Region.

Owing to application of state-of-the-art technologies, Leningrad Region demonstrates the leading indices of per cow milk yields in the country, Fig. 3.

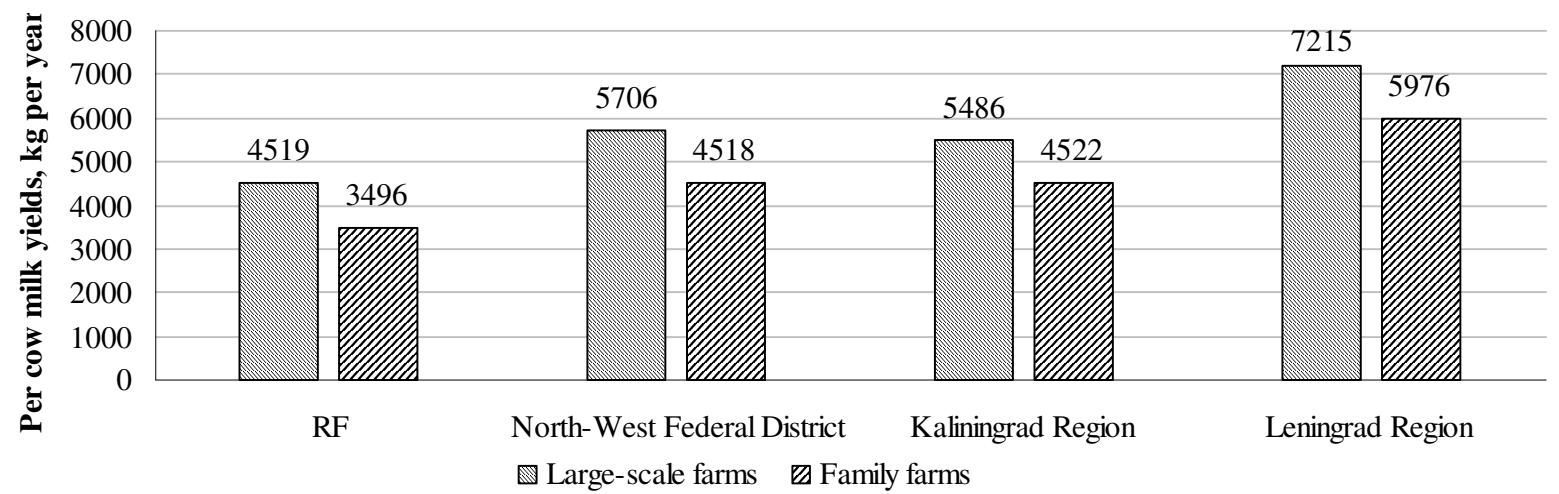

Fig. 3. Per cow milk yields on large-scale farms and family farms/personal smallholdings (as of 2014, Federal State Statistics Service)

In Leningrad Region there are several agricultural enterprises with the milk yield over $9000 \mathrm{~kg}$ per year. The economic indicators of an advanced farm are as follows: animal stock - 3324 head, including 1350 cows; average annual milk yield $-11060 \mathrm{~kg}$ per cow; 80 calves per 100 cows.

The milk production technologies were considered in terms of BAT and the interrelation of all the flows within the main technological processes, Fig. 4. 


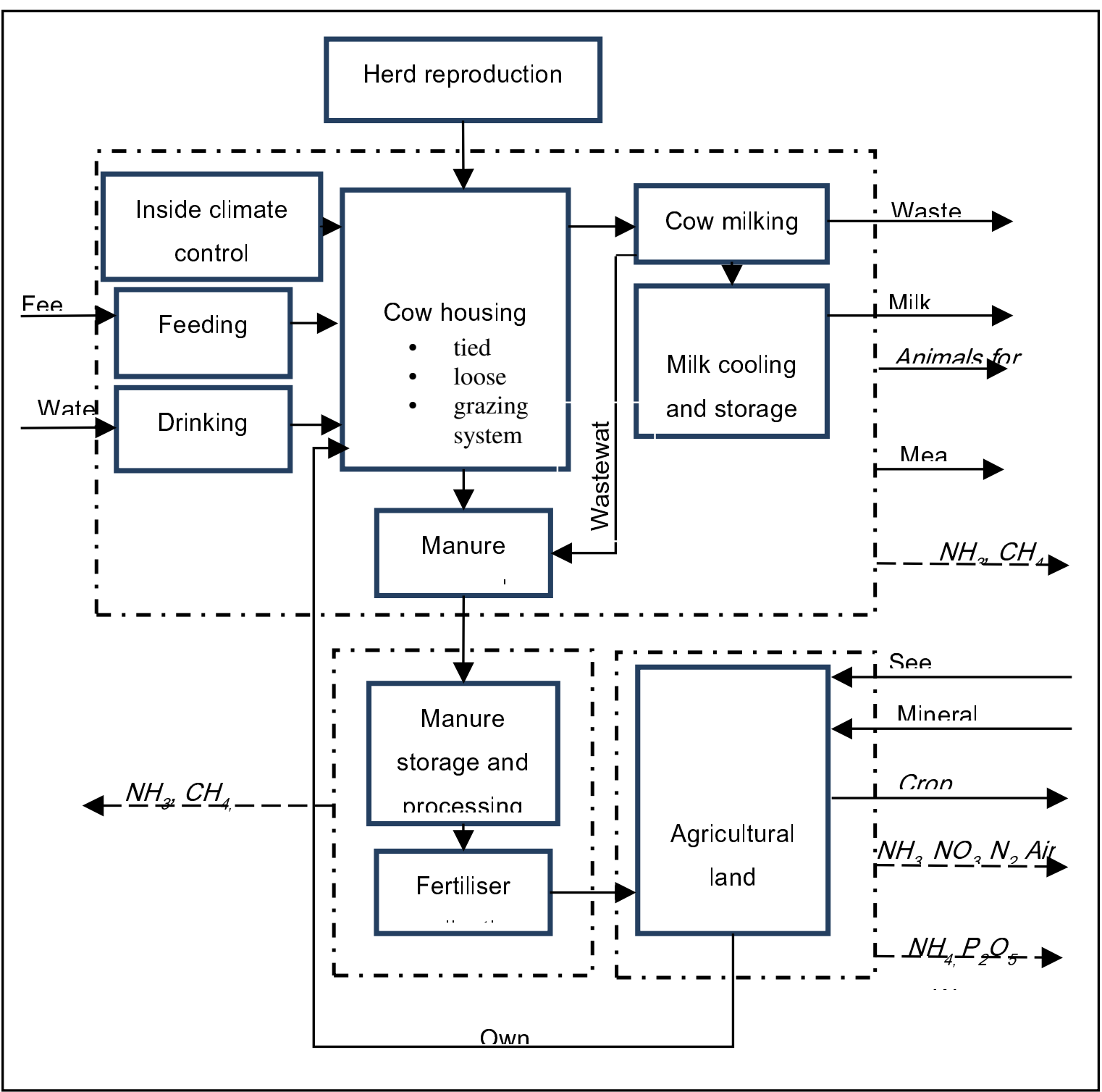

Fig. 4. Functional and structural diagram of production processes on dairy farm

The survey of dairy farms in Leningrad Region revealed the most common type to be an enterprise with both livestock and crop production. It has a herd reproduction block, dairy herd proper, manure handling system and agricultural land for own fodder production. The diagram also shows the main external and internal links between the blocks in the form of nutrient flows. It seems sensible to assess a dairy farm for environmental compliance on the basis of such understanding of interrelated on-farm flows. The survey was conducted by the authors in 2015.

Material (nutrients) flows, which characterize the farm performance, are:

- inputs: feed, bedding, mineral fertilisers, seeds

- outputs: milk, meat, pedigree animals, crop production.

Environmental impact (nutrients loss):

- from animal housing to air: $\mathrm{NH}_{3}, \mathrm{CH}_{4}, \mathrm{~N}_{2} \mathrm{O} ; \mathrm{CO}_{2}$

- from manure removal system to air: $\mathrm{NH}_{3}, \mathrm{CH}_{4}, \mathrm{~N}_{2} \mathrm{O}$

- from the fields: to air $-\mathrm{NH}_{3}, \mathrm{CH}_{4}, \mathrm{~N}_{2} \mathrm{O}$, to water $-\mathrm{NH}_{4}, \mathrm{P}_{2} \mathrm{O}_{5}$.

Based on the proposed structure, the findings of pilot farms survey in Leningrad Region, and the results of many years of research in IEEP [15; 16], recommendations were issued on the development of BAT reference books for intensive livestock production [17]. They specify the list of questions to 
be included in the questionnaires when collecting the data and describe the dairy cow housing practices in BAT format.

Manure handling and fodder production technologies on cattle farms are basically similar to those used in pig rearing. The list of indicators and criteria to identify BAT roughly coincides with the BAT indicators used in the assessment of pig enterprises; the main difference is the housing and milking technologies. The analysis showed that, when choosing and identifying technologies as BAT in dairy farming, some environmental issues do not have a single solution and require additional research. These are cross-cutting issues related to transition to intensive livestock production - animal welfare, the choice of animal housing type, the increase in cow productivity, importance of the grazing system, harmonization of measures to reduce ammonia emissions and emissions of greenhouse gases.

Table 1 shows the operation indicators of a typical farm used to identify BAT.

Table 1

\section{General characteristics of a technology (as exemplified by a farm} with 1150 cows, including 960 milk cows)

\begin{tabular}{|c|c|c|}
\hline Indicator & Value & Unit \\
\hline \multicolumn{3}{|c|}{ Production system } \\
\hline Breed & \multicolumn{2}{|c|}{ Black and white Holstein } \\
\hline Milk cows & 960 & head \\
\hline Calves per 100 cows & 85 & head per year \\
\hline Servicing period & 120 & day \\
\hline Culling rate & 0.3 & head per year \\
\hline Period of productive cow use & 3.3 & Lactations \\
\hline \multicolumn{3}{|c|}{$\begin{aligned} \text { Resource consumption } \\
\end{aligned}$} \\
\hline Drinking water & 100 & l per head per day \\
\hline Process water & 15 & 1 per head per day \\
\hline Power inputs for manure removal & 14 & kWh per head per year \\
\hline Power inputs for lighting & 60 & kWh per head per year \\
\hline Power inputs for milking & 105 & kWh per head per year \\
\hline Bedding & 0.5 & kg per head per day \\
\hline \multicolumn{3}{|c|}{ Product yield } \\
\hline Milk & 9000 & kg per head per year \\
\hline Manure & 20.2 & $\mathrm{t}$ per head per year \\
\hline Sale of pedigree animals & 100 & Bred heifers per year \\
\hline Labour inputs & 1.5 & Man hour per $100 \mathrm{~kg}$ of milk \\
\hline
\end{tabular}

In dairy farming, animal welfare requirements have a significant effect on environmental performance. It is known that one of the main reasons for the transition from tied to loose housing is to ensure the welfare of animals by increasing the room area per head. The consequences were new technologies, an increase in the floor area soiled with manure, and $50 \%$ increase in ammonia emissions from the premises with loose housing. Transition to loose housing resulted in substantial increase in the volume of manure produced due to its higher moisture content [15]. Improved performance of cows is one of the reasons why the grazing system is not widely used. However, it is believed to be a method to reduce air emissions. High performance of cows and their loose housing also cause the shorter period of productive cow use, with the average number of lactations being 2.5-3. However, it was demonstrated that the main method to reduce the greenhouse gas emissions (methane and carbon dioxide) [9] is the general reduction of animal stock through a lower number of animals in the reproduction sector under the longer life expectancy of dairy cows.

All this suggests that in modern technologies with loose cow housing and large volumes of liquid manure the realistic method to reduce emissions and discharges is to improve the manure handling systems. Introduction of BAT technologies for manure processing, storage and field application will allow reducing atmospheric ammonia emissions by, at least, $20 \%$ and, consequently cutting down the nitrogen loss [18]. 
One of the most important issues in the development of the BAT reference book on cattle rearing is the environmental assessment when identifying the BAT candidates. The complex nature of economic, ecological, and technological interrelations in milk production makes it necessary to consider the entire production chain when assessing the environmental impact and when justifying the measures to reduce emissions and discharges from the dairy farm. One of the directions for implementing such an approach is the application of nutrient efficiency indicators for the environmental assessment of a livestock enterprise.

In $[17 ; 18]$ it is shown that when the farms are assessed on the stage of integrated permits issue, it is feasible to use the measured air concentrations of hazardous substances along with the estimation of the whole-farm environmental impact by nitrogen use efficiency (NUE). NUE is an integrated index of environmental load and meets all requirements to an indicator: it is easy to calculate, convenient to compare, understandable to the farmer and can be verified in case of falsification. For such estimates to be applied in Russia, the data need to be collected and systematised for different categories of farms and for different climatic regions.

The conducted approximate calculations of farm-gate balance for pilot dairy farms in Leningrad Region based on the available statistical reporting of the enterprise $[17 ; 18]$ showed the NUE values in the range of 0.21-0.34 that was below the European level [9]. To substantiate the provisions of the BAT reference book on cattle rearing, additional research is needed to determine the ways to increase NUE and to reduce the nitrogen loss from all technological processes on the dairy enterprise.

\section{Conclusions}

1. The need for transition to the BAT system in intensive cattle rearing in Russia is explained by the significant contribution of this sector to environmental pollution, and, accordingly, the requirements to take effective measures to reduce its negative impact. Ammonia emissions from cattle farms in the European part of Russia account for $40 \%$ of the emissions from all animal categories and in Leningrad Region $-74 \%$.

2. To determine the structure of the BAT reference book on cattle rearing and to collect the initial data it seems practical to use the functional and structural diagram of the production processes on a dairy farm shown in Fig.4.

3. Analysis of the technological processes of milk production on the farms in Leningrad Region shows that one of the key components in the complex problem of emission and discharge reduction from the dairy farming is to introduce BAT of manure handling.

4. To substantiate the selection of BAT on cattle rearing additional comprehensive interdisciplinary research is needed related to assessment of nutrients use efficiency, emissions and discharges into environment from the whole production chain for different cattle housing practices (tied, loose, grazing and all-year-round indoor housing) in various climatic zones.

\section{References}

[1] The Federal law "On introducing some amendments into the Federal Law "On Protection of Environment" and other legislative acts of the Russian Federation” of 21.07.2014 № 219-Ф3. [online] [31.01.2018]. Available at: http://www.consultant.ru/document/cons_doc_ LAW_165823/ (In Russian)

[2] Directive 2010/75/EU of the European Parliament and of the Council of 24 November 2010 on industrial emissions (integrated pollution prevention and control) [online] [05.03.2018]. Available at: http://eur-lex.europa.eu/legal-content/EN/TXT/?uri=CELEX:32010L0075

[3] Information and technical BAT reference book "Intensive rearing of pigs". 2017. [online] [05.03.2018]. Available at: http://www.burondt.ru/NDT/NDTDocsDetail.php?UrlId= 1138\&etkstructure_id=1872 (In Russian)

[4] Information and technical BAT reference book "Intensive rearing of farm poultry". 2017. [online] [07.02.2018]. Available at: http://www.burondt.ru/NDT/NDTDocsDetail.php?UrlId= 1140\&etkstructure_id=1872 (In Russian)

[5] Santonja G. , Georgitzikis Konstantinos, Scalet Bianca Maria, Montobbio Paolo, Roudier Serge, Sancho Luis Delgado. 2017.Best Available Techniques (BAT) Reference Document for the Intensive Rearing of Poultry or Pigs; EUR 28674 EN; DOI:10.2760/020485 
[6] EMEP/EEA emission inventory guidebook 2013 update July 2015. 3. B Manure management. [online] [05.03.2018]. Available at: https://www.eea.europa.eu/publications/emep-eea-guidebook2013/part-b-sectoral-guidance-chapters/4-agriculture/3-b-manure-management

[7] Order of the Ministry of Natural Resources and Environment of the Russian Federation № 300 of 30.06.2015 "On approval of methodological guidelines and the guidance document on the quantitative determination of greenhouse gas emissions by organisations engaged in economic and other activities in the Russian Federation" [online] [07.02.2018]. Available at: http://www.rosteplo.ru/Npb_files/npb_shablon.php?id=1740 (In Russian)

[8] Pollution prevention and control, Best Available Techniques for Intensive Rearing of Cattle Tartu 2007 [online] [07.02.2018]. Available at: http://www.ippc.envir.ee/docs/ PVT/BAT \%20for \%20Intensive \%20Rearing \%20of \%20Cattle.pdf

[9] Bittman S., Dedina M., Howard C.M., Oenema O., Sutton M.A., (eds). Options for Ammonia Mitigation: Guidance from the UNECE Task Force on Reactive Nitrogen, Centre for Ecology and Hydrology, Edinburgh, UK, 2014.

[10] Management Directive for Agro-Industrial Complex (RD-APK) 1.10.01.02-10 Recommended Practice for Engineering Designing of Cattle Farms. 2011. Ministry of Agriculture and Food of the Russian Federation. [In Russian]. Metodicheskiye rekomendatsii po tekhnologicheskomu proyektirovaniyu ferm i kompleksov krupnogo rogatogo skota RD-APK 1.10.01.02-10 Moskva MSKH R (In Russian)

[11] Management Directive for Agro-Industrial Complex "Recommended Practice for Engineering Designing of Systems for Animal and Poultry Manure Removal and Pre-application Treatment" РД-АПК 1.10.15.02-17 [online] [07.02.2018]. Available at: http://libnorm.ru/Directory2/1/4293744/4293744162.htm. (In Russian)

[12] State standard R 56828.14-16 Best available techniques. Structure of information and technical reference book. Moscow. Standartinform Publ. 2016. [online] [15.02.2018]. Available at: http://www.internet-law.ru/gosts/gost/63554/ (In Russian)

[13] Subbotin I., Vasilev E. Formalization of criteria for determining best available technologies: the case of Russia//Engineering for rural development. Proceedings. 2016. P. 845-850.

[14] Briukhanov A., Subbotin I., Uvarov R., Vasilev E. Method of Designing of Manure Utilization Technology//Agronomy Research. 2017. Vol. 15. № 3. P. 658-663

[15] Khazanov E.E., Gordeev V.V., Khazanov V.E. Modernisation of dairy farms. Saint Petersburg, SZNIIMESH Publ., 2008. 380 p. (In Russian)

[16] Surovtsev V.N., Nikulina Yu.N., Gordeev V.V., Khazanov V.E. Efficincy of technological modernization of dairy farming. Milk and Beef Cattle Rearing. 2017. no.4, pp.5-10. (In Russian)

[17] Briukhanov, A. Yu., Kozlova, N.P.,.Vasilev, E.V.,Shalavina E.V. 2016.Recommendations how to identify the BATs for intensive livestock farming in IEEP Publishers, Saint Peterburg. Rekomendatsii po opredeleniyu nailuchshikh dostupnykh tekhnologiy dlya intensivnogo zhivotnovodstva. (In Russian)

[18] Kozlova N., Briukhanov A., Vasilev E., Shalavina E. Environmental assessment of livestock farms in Russia. Bioecnomy challenges pp. 330-336. DOI: http://doi.org/10.15544/RD.2017.189 